\title{
Online dagbogen i praktik- og klinikforløb på sundhedsvidenskabeli ge uddannelser
}

\section{Janne Saltoft Hansen}

E-læringskonsulent

Aarhus Universitet, Center for Medicinsk

Uddannelse

\section{Jeanette Lyk}

Tandplejer, Faglærer

Aarhus Universitet, SKT

\section{Sanne Pedersen}

Tandplejer, Faglærer Aarhus Universitet, SKT
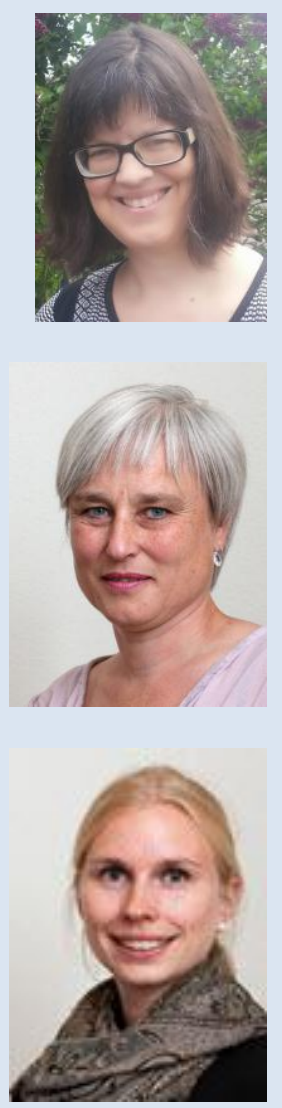


\section{Dansk abstract}

Færdighedstræning gennem praktik- og klinikforløb er en vigtig del af de sundhedsvidenskabelige uddannelser. På tandplejeruddannelsen på Aarhus Universitet fører de studerende gennem hele praktikforløbet en online dagbog, hvor indlæggene er styret i forhold til en obligatorisk opgave, som på forhånd er stillet af underviserne. Dagbogen læses og kommenteres undervejs af underviserne.

Det værktøj, som de studerende bruger til dagbogen, har de fået gennem Aarhus Universitets nye learning management system, Blackboard, og værktøjet findes derfor integreret der, hvor de studerendes normale online aktiviteter foregår.

I artiklen fremlægges de studerende og undervisernes erfaringer med brug af online dagbogen til understøttelse af et praktikforløb og de studerendes kommunikationstræning. Artiklens formål er at undersøge, hvorvidt læring og færdighedstræning i praktikken styrkes gennem løbende skriftlig refleksion, og hvilken betydning online dagbogens muligheder for kontinuerlig feed back giver i den forbindelse.

Videre diskuteres implementeringen af værktøjet i uddannelsen, og der gives perspektiver på håndtering af ressourceforbruget til e-moderation i den fremtidige drift.

\section{English abstract}

Skill training in clerkship is a significant part of health education. At the Dental Hygienists Education at Aarhus University the students are keeping an online journal during their clerkship. Journal documentation is an obligatory assignment and the journals are continuously read and commented by the teachers.

The journal tool is facilitated using Aarhus University's new learning management system, Blackboard, and is integrated in the students' usual online activities.

This article presents the students' and teachers' experiences using the online journal to support the clerkships and communication skills. The objective of the article is to explore whether education and skills training in clerkships are supported by ongoing written reflections and to further examine the importance of commenting and feedback.

The article discusses the implementation of the journal tool and the usage of resources to e-moderate on daily basis. 


\section{Introduktion}

Færdighedstræning i form af praktik og klinikophold er en væsentlig del af de sundhedsvidenskabelige uddannelser. Her får de studerende i praksis afprøvet det, de lærer på studiet, i samarbejde med uddannede kolleger og $\mathrm{i}$ kontakt med patienter. Der er ingen tvivl om, at den praktiske træning af færdigheder er yderst gavnlig for de studerende, men samtidig betyder praktik og klinikophold, at de studerende bruger lang tid væk fra uddannelsesstedet, og det kan være vanskeligt i disse perioder at understøtte sammenhængen mellem det praktiske og teorien.

Learning management systemet (LMS), som er et system til online læring, har den fordel, at den læring der foregår her er uafhængig af tid og sted. I LMS'et skabes der derfor mulighed for, at undervisning ikke nødvendigvis skal foregå, når underviser og studerende er til stede i samme lokale, men undervisningen kan udvides til også at omfatte de perioder, som ligger mellem forelæsninger eller i praktikforløb. Herved bliver det i LMS'et muligt for underviser og studerende at bevare kontakten under de lange praktik- og klinikophold.

I et LMS kan tilbydes mange typer af værktøjer til understøttelse af denne kontakt, som f.eks. wikis og diskussionsfora, der er samarbejdsværktøjer, der oftest bruges i fællesskab af alle studerende. I denne artikel vil fokus blive lagt på dagbogen, som er et mere personligt redskab, og på de fordele, som dagbogen giver for at styrke den studerendes refleksion under praktik- eller klinikophold. Artiklen tager udgangspunkt i en case fra tandplejeruddannelsen på Aarhus universitet og undersøger brugen af online dagbogen som refleksionsredskab i et længere praktikforløb på uddannelsen. Dagbogens betydning for refleksionen belyses ved hjælp af Schöns teorier om reflection-in-action og reflection-on-action, mens Hattie og Timperleys feed back-teori danner grundlag for en analyse af undervisernes dagbogskommentarer.

Til slut giver artiklen gennem erfaringer fra Aarhus Universitet, sammenholdt med guidelines fra Southeastern Louisiana University, et bud på, hvordan integrationen af en online dagbog kan håndteres i uddannelser med praktik eller klinikophold, både hvad angår de studerendes indlæg og undervisernes ressourceforbrug til kommentarer.

\section{Case: Tandplejeruddannelsen}

Tandplejeruddannelsen er en professionsbachelor på Skolen for klinikassistenter, tandplejere og kliniske tandteknikere (SKT) på Aarhus Universitet. Uddannelsen er bredt sammensat af sundheds- og naturvidenskabelige fag, humanistiske og samfundsvidenskabelige fag, samt odontologiske fag fra tandplejerfaget. 
Tandplejeruddannelsen er opdelt i 12 moduler med hver sit overordnede tema, der behandles gennem de forskellige faglige kerneområder på modulet. $30 \%$ af uddannelsen består af intern eller ekstern praktik fordelt på flere mindre praktikker af få dages varighed og to længerevarende eksterne praktiker.

På modul 10, hvor temaet er Tandpleje - kvalitetssikring, klinisk ræsonnering og behandling har de studerende den længste praktik, da de i 4 uger er i ekstern praktik i den kommunale tandpleje.

\section{Online dagbogen}

I efteråret 2013 startede implementeringen af Aarhus Universitets fælles learning management system (LMS). Universitetet har valgt det kommercielle system Blackboard, der skal erstatte en bred vifte af eksisterende systemer og samtidig være et redskab til at indfri mål i Aarhus Universitets fælles politik for Educational IT. I politikken defineres Educational IT som en syntese af teknologisk, pædagogisk og didaktisk nytænkning, hvis mål er kvalitetsudvikling af undervisningen og uddannelserne.

Et af de værktøjer, som er tilgængelige i Blackboard, er dagbogen (Journal). En dagbog er udformet på samme måde som en blog og består således af en række indlæg og kommentarer til indlæggene. Alle indlæg er grupperet i uger og sorteret med det nyeste indlæg øverst. Det angives med ikoner, om der er nye indlæg eller kommentarer. Det, der adskiller dagbogen fra bloggen, er de rettigheder, som forskellige brugere på et kursus har til at skrive og se indlæg og kommentarer. Hvor bloggen er offentlig, således at indlæg og kommentarer kan ses af alle, er dagbogen personlig, og indlæg kan derfor kun ses af den studerende, der har skrevet det og de undervisere, der er tilknyttet kurset. Kommentarer kan skrives og læses både af den studerende, der ejer dagbogen og de tilknyttede undervisere.

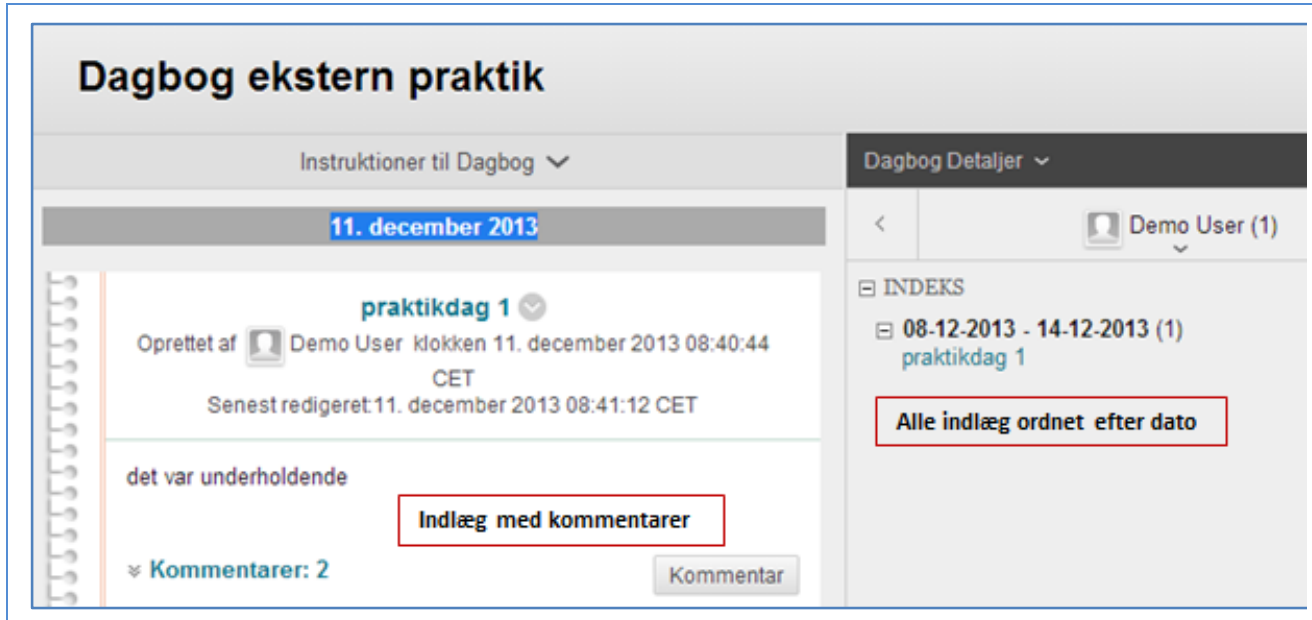

Figur 1. 


\section{Opgaven}

På tandplejeruddannelsen blev modul 10 en del af de første pilotprojekter på Blackboard. Ca. 60 studerende fik adgang til systemet, og det samme gjorde alle undervisere på uddannelsen, men kun 15 af disse var direkte involverede i modulet.

Modultemaet Tandpleje - kvalitetssikring, klinisk ræsonnering og

behandling lægger op til, at de studerende skal reflektere over egen praksis, hvad de gør, og hvordan deres arbejde kvalitetssikres. Dette er derfor også den primære grund til, at man på modulet valgte at bruge et værktøj som online dagbogen, da dette netop lægger op til refleksion.

For at styrke refleksion frem for deskription, blev der er stillet en bunden opgave til de studerende, som gik ud på dagligt at besvare følgende 3 punkter i dagbogen:

a. Et fagligt tema, der er nyt for dig (en behandling, en procedure, en tilgang, en værdi eller lignende)

b. Det har jeg lært i dag:

c. Det vil jeg gerne vide mere om:

Endvidere skulle de studerende sidst i forløbet sammenfatte deres erfaringer med tre eksempler på, hvordan praktikstedet sikrer kvaliteten af tandplejen. Se den fulde ordlyd af opgaven i figur 2 .

Temaet for modul 10 er "Kvalitetssikring, klinisk ræsonnering og behandling", og disse temaer skal I også arbejde med i praktikken, hvilket jeres praktikværter er blevet orienteret om.

I løbet af praktikperioden skal I gøre følgende:

1. Giv 3 eksempler på, hvordan dit praktiksted sikrer kvaliteten af tandplejen, gerne både på institutions-, afdelings-, og individniveau. Tal gerne med medarbejderne på praktikstedet om emnet. Eksemplerne fører du ind i dagbogen på Blackboard.

2. Redegør dagligt kort (max. $1 / 2$ side) for

a. Et fagligt tema, der er nyt for dig (en behandling, en procedure, en tilgang, en værdi eller lignende)

b. Det har jeg lært i dag:

c. Det vil jeg gerne vide mere om:

Jeres kontaktlærer ser jeres dagbøger og vil evt. kommentere i dem. Det er også muligt for andre undervisere at se dem, men I kan ikke se hinandens dagbøger.

Figur 2 


\section{Indlæg og kommentarer}

Hver studerende har gennem hele uddannelsen en kontaktlærer, som således kender den studerende godt, når den studerende er nået til modul 10. Før praktikforløbet blev det besluttet, at den hovedansvarlige for kommentarerne til hver enkelt studerende var den pågældende studerendes kontaktlærer. Hver underviser var derfor ansvarlig for at læse og kommentere et varierende antal indlæg afhængigt af det antal studerende, man var kontaktlærer for. Flere undervisere læste dog indlæg, som ikke var skrevet af deres egne studerende og kunne også kommentere på disse.

For at kunne overkomme den opgave, det er at læse og kommentere de mange indlæg, blev det meldt ud til de studerende, at alle indlæg ville blive læst, men at man ikke kunne forvente at få kommentarer. De fleste studerende fik dog kommentarer i forløbet.

Alt i alt blev der i de fire uger praktikken varede oprettet 846 indlæg af 62 studerende. Reelt er antallet af indlæg en smule højere, da nogle få har brugt dagbogen anderledes end den er tiltænkt ved at lægge flere dage under samme indlæg, mens en enkelt afleverede dagbogen via mail. Typisk har en studerende skrevet 15-18 indlæg. Hertil kommer 138 kommentarer, der oftest er skrevet af undervisere, men også af studerende som svar på spørgsmål i undervisernes kommentarer.

Dagbogen, der er en del af pilotprojektet på tandplejeruddannelsens modul 10, er fulgt under implementeringen af Blackboard på Health, hvor der har været adgang til samtlige dagbogsindlæg og kommentarer. Efterfølgende er foretaget samtaler med to undervisere på modulet.

\section{Reflection-in-action og reflection-on-action i praktikforløbet}

Læring kan enten foregå implicit eller eksplicit (Fredens, 2012), hvor implicit læring er den læring, der finder sted uden at den lærende tænker over, hvordan der læres, mens der ved eksplicit læring reflekteres over det lærte. Fredens bekriver ved hjælp af eksperimenter foretaget af Berry og Broadbent i 1984, hvordan implicit læring ofte foregår hurtigere end eksplicit læring. Personer der anvender implicit læring tilegner sig på kortere tid færdigheder end personer, der anvender eksplicit læring. Omvendt styrker den eksplicitte læring og refleksioner den lærendes selvtillid omkring det lærte og danner grundlag for, at den nye viden kan forbedres og bruges i andre sammenhængen end hvor, det er lært. Det er altså en fordel at kombinere den implicitte og eksplicitte læring og understøtte praktisk erfaring med refleksion.

Hensigten med at bruge dagbogen som et værktøj har netop været understøttelse af den studerendes refleksion under praktikforløbet, og det http://www.lom.dk 
er derfor interessant at undersøge, hvad der er karakteristisk for refleksion, som finder sted i forbindelse med praktisk handling. Hos Donald A. Schön defineres flere typer af refleksion (Schön, 1991). Mange tillærte handlinger, som f.eks. cykling, udføres, uden at praktikeren tænker nærmere over sin handling. Schön kalder dette for knowing-in-action. Ind imellem får praktikeren dog problemer, eller der opstår situationer, der vækker undren. Praktikeren må da standse op og reflektere nærmere over sin handling og muligvis ændre handlingen i forhold til refleksionen. Dette kalder Schön for reflection-in-action. Senere, hvis praktikeren igen begynder at reflektere over den udførte handling, kalder Schön det for reflection-on-action.
"A practitioner such as a lawyer, a teacher, or a machinist may reflect in this way on a particular episode of reflection-in-action or on a sequence of such episodes, thereby making explicit and subjecting to critique and testing the strategies, assumptions, or problem-settings implicit in a whole repertoire of situational responses."

(Schön, 1995)

Dette betyder at der opstår en tidsmæssig forskydning mellem de to refleksionsformer. Hvor reflection-in-action er den refleksion der foregår, mens det stadig er muligt at ændre sin handling, så er reflection-on-action en refleksion der peger fremad og påvirker fremtidige handlinger.

\section{"But our reflection on our past reflection-in-action may indirectly shape our future action."}

(Schön, 1991, p31)

Samtidig er der ifølge Schön ikke blot tale om en iterativ proces, hvor fremtidige handlinger påvirkes neutralt, men der sker en værdiladet fremdrift, hvor praktikeren har mulighed for at bliver dygtigere. Der kan sættes gang i en læreproces. Han beskriver dette med et eksempel, hvor han selv udførte tømrerarbejde på amatørbasis:

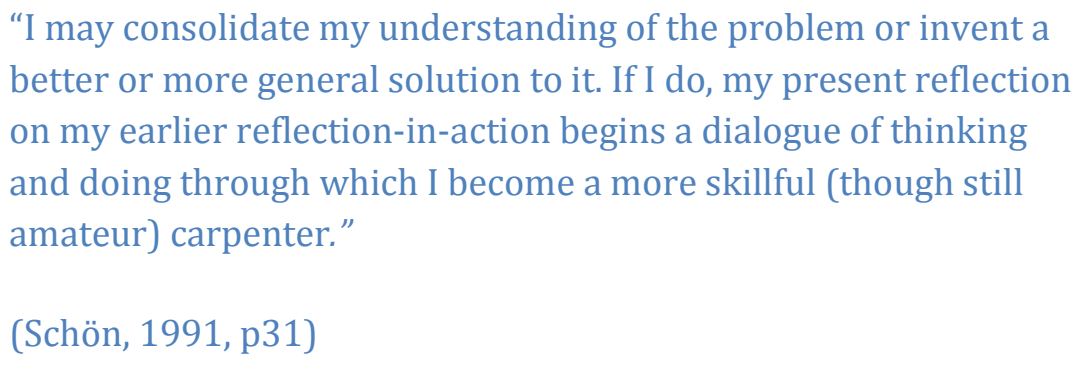


Samtidig sker der i denne proces af reflection-in-action og reflection-onaction et reflective transfer (Schön, 1995), der betyder at refleksioner kan projekteres til nye situationer.

"Through these processes of reflection-in-action and reflectionon-action, the newly generated practice knowledge may be modified and incorporated into the practitioner's repertoire so as to be available for projection to further situations."

(Schön, 1995)

I et praktikforløb bliver den studerende sat udenfor den normale undervisningssituation og skal lære via praktisk erfaring. Som studerende vil man hyppigt, og sandsynligvis i højere grad end den erfarne praktiker, komme i situationer, hvor man må tænke over sine handlinger. Den studerende veksler derfor ofte fra situationer med knowing-in-action til situationer, hvor den studerende må reflektere over sin aktuelle praksis og benytte sig af reflection-in-action.

Senere, når den studerende reflekterer over sine handlinger og disse refleksioner bruges i forbindelse med fremtidige handlinger, er der tale om reflection-on-action. Som det ses af ovenstående, har det stor betydning for den studerendes læreproces og evne til at bruge det praktisk lærte i nye sammenhænge, at den studerende faktisk făr reflekteret over sine handlinger efterfølgende.

På tandplejeruddannelsen vil man gerne styrke disse efterfølgende refleksioner gennem formaliserede skriftlige afleveringer. Tidligere foregik dette ved, at den studerende skrev en praktikrapport til praktikkoordinatoren, og ved indførsel af det nye LMS er det derfor første gang, at tandplejeruddannelsen benytter online dagbogen som redskab. I forhold til refleksion er der stor forskel på de to opgavetyper. I både praktikrapport og dagbog er der tale om reflection-on-action, da den studerende reflekterer efter selve handlingen og ikke har mulighed for at ændre de udførte handlinger som følge af disse refleksioner. Men hvor praktikrapporten er refleksion efter, at praktikforløbet er færdigt, kan den studerende i dagbogen løbende nedskrive sine refleksioner under hele forløbet. Herved får den studerende gennem sine refleksioner i dagbogen mulighed for at påvirke næste dags handlinger. Eller sagt på en anden måde kan den studerende gennem reflection-on-action påvirke efterfølgende reflection-in-action i det samme praktikforløb. Den studerende går fra et refleksionsloop til en refleksionsspiral. (Se figur 3) 


\section{Reflection-in-action}

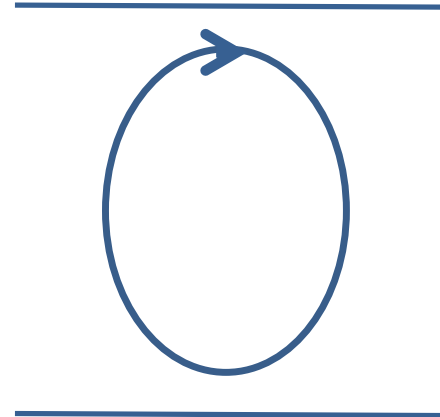

Reflection-onaction

\section{Reflection-in-action}

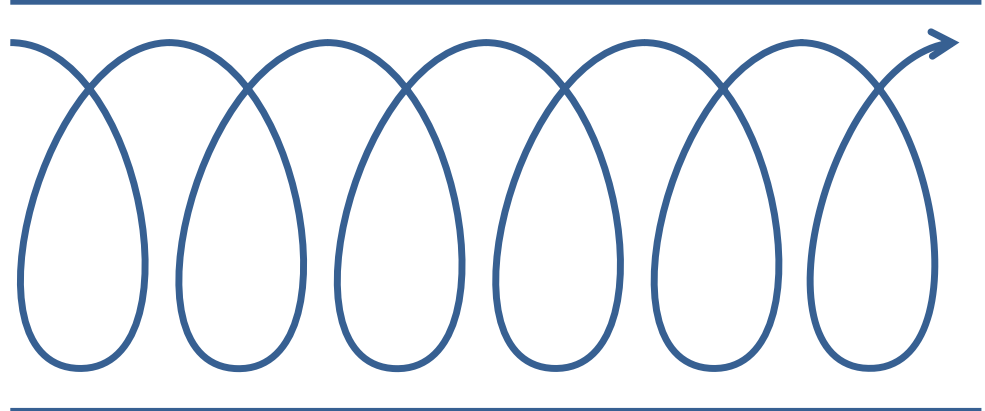

Reflection-on-action

Figur 3

\section{Kommentarerne}

Dagbogen har betydning i et praktikforløb, fordi den giver mulighed for gennem reflection-on-action at reflektere over dagens handlinger og påvirke næste dags reflection-in-action. Online dagbogen adskiller sig på dette punkt ikke fra en almindelig dagbog, som den studerende løbende vedligeholder. Det, der gør online dagbogen ekstra interessant, er kommentarerne, og den mulighed disse giver for feed back til den studerende gennem forløbet.

I deres feed back-model beskriver Hattie og Timperley, hvordan effektiv feed back besvarer tre spørgsmål (Hattie \& Timperley, 2007):

- Feed Up (mål): Hvor skal jeg hen? ("Where am I going?")

- Feed Back: Hvor er jeg i lærerprocessen? ("How am I going?")

- Feed Forward: Hvad er næste skridt? ("Where to next?")

Effektiv feed back er derfor ikke blot et spørgsmål om at give den studerende svar på, hvordan det går, men peger også i høj grad frem mod et mål og de næste handlinger, der fører mod målet. Her kan det være en fordel for den studerende, at de handlinger, der peges frem imod, ligger inden for en overskuelig fremtid. Feed back og feed forward på en praktikrapport er en respons på et afsluttet og ret lukket forløb, mens online kommentarer i dagbogen kan afgives løbende gennem praktikforløbet med mulighed for at påbegynde de næste skridt allerede den efterfølgende dag. 
Med løbende online kommentarer til den studerende bliver der med andre ord mulighed for at bryde ind i refleksionsspiralen og påvirke den studerendes refleksion, mens den studerende stadig er i praktikforløbet. (Se figur 4)

\section{Reflection-in-} action

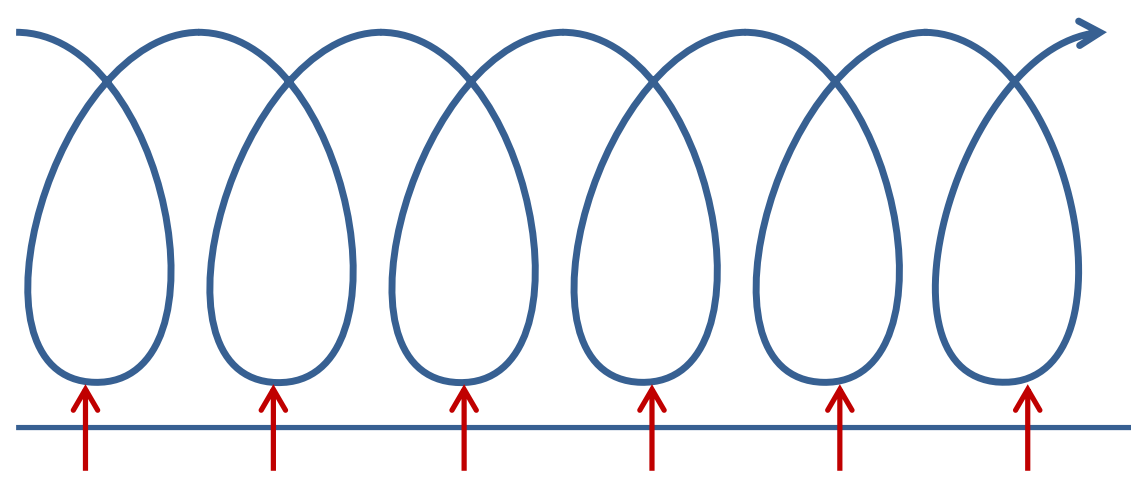

Reflection-onaction

Påvirkninger gennem online kommentarer

Figur 4

Som et eksempel på, hvordan refleksionsspiralen brydes, beskriver en underviser, hvordan de studerende undervejs i praktikforløbet skulle samle op på deres refleksioner i dagbogen og sammenfatte de tanker, de havde gjort sig. Når dette ikke var påbegyndt efter de første uger, blev det påpeget af underviseren, hvorefter de studerende ændrede deres refleksioner til også at omfatte opsamling og refleksion over tidligere refleksioner. På denne måde påvirkede underviseren de studerendes refleksionsproces.

Kommentarerne betyder derfor, at det bliver nemmere for underviserne ikke blot at give den studerende feed back på praktikforløbet, men også en feed forward der peger frem mod målet for praktikforløbet.

For eksempel oplevede en underviser, at en studerende var ærgerlig over, at der ikke i det program, der var lagt for hende, var afsat tid sammen med en tandlæge, hvilket ellers kunne være en god mulighed for at se den praktiske behandling af blandt andet cariesdiagnoser, som stilles af tandplejeren. Underviseren rådede den studerende til at forhøre sig om muligheden for at se tandlægens arbejde på trods af det planlagte program, og herefter blev programmet ændret. 
På denne måde tilskynder underviseren ved brug af feed forward den studerende til at ændre sine handlinger, således at den studerende $\mathrm{i}$ praktikken når målet om at se tandlægens arbejde. Havde der været tale om efterfølgende feed back på en praktikrapport, havde det været for sent for den studerende at nå dette mål.

\title{
Indhold i kommentarere
}

Undervisere kan følge en specifik feed back-strategi, når de kommenterer på dagbogsindlæg. Det er dog et stort arbejde at kommentere, og på tandplejeruddannelsen har man i første omgang ikke valgt nogen strategi. Hverken hvad angår indhold, eller hvor ofte de studerende skal modtage kommentarer. Alle dagbogsindlæg skal dog læses løbende, og den studerende skal have kommentarer mindst en gang gennem forløbet. På denne måde vil underviserne sikre, at uddannelsen kommer godt i gang med at bruge online dagbogen, og at det bliver en overkommelig opgave at kommentere.

Primært falder de kommentarer, som underviserne har givet inden for fire kategorier:

- Kommentarer, der skal sikre at det går godt i praktikken

- Kommentarer, der bekræfter at indlægget er læst, og den studerende er på rette spor

- Kommentarer, der tilskynder videre refleksion

- Kommentarer, der skal vise den studerende vej mod ny viden

\section{Kommentarer, der skal sikre at det går godt i praktikken}

På tandplejeruddannelsens modul 10 er det påkrævet, at den studerende skal skrive dagbog hver dag, og har den studerende ikke har skrevet dagbog i et stykke tid, bruger underviseren kommentaren til at høre, hvordan det går den studerende, og hvad årsagen er til, at der ikke kommer indlæg fra den pågældende studerende. Nogle gange er der en simpel forklaring, som sygdom, men andre gange skyldes manglen på indlæg et dårligt praktikforløb. Online dagbogen og den løbende kontakt med den studerende giver derfor underviseren mulighed for at gribe ind og få praktikforløbet tilbage på sporet, før det er for sent. Resultatet er, at alle studerende på dette modul har haft et fornuftigt praktikforløb.

\section{Kommentarer, der bekræfter at indlægget er læst og den studerende er på rette spor}

\author{
"God læsning i dine dagbøger. Dejligt du lærer så meget." \\ "Gode erfaringer og observationer du gør dig :)"
}


"Det lyder spændende med alt det nye du lærer. Håber du trives i det. God arbejdslyst."

Mange af de kommentarer, som underviserne giver de studerende, er kommentarer, hvis funktion det er at bekræfte over for den studerende, at der er nogen der læser dagbogen i den anden ende. Dette er især vigtigt, fordi mediet er nyt for de studerende, og kommentarerne bekræfter derfor, at teknikken fungerer, og at underviserne bruger det som aftalt.

Samtidig giver disse kommentarer de studerende en mulighed for at holde kontakten med uddannelsesinstitutionen, hvilket giver tryghed og sikkerhed for den studerende, som befinder sig i en fremmed situation. En underviser beskriver det som en "linje tilbage til skolen".

Dagbogskommentarerne giver derfor den studerende en vished for, at de er på rette spor og kan håndtere den uvante situation de befinder sig i.

\section{Kommentarer, der tilskynder videre refleksion}

Hvor de to første typer af kommentarer er bekræftende kommentarer, der primært peger bagud og giver den studerende svar på, hvordan det går, lægger en anden gruppe af kommentarer sig i højere grad op af Hattie og Timperleys definition af feed forward. Det er kommentarer, der tager udgangspunkt i den studerendes nuværende situation, og samtidig tilskynder til videre refleksion.

En del kommentarer, har her til formål at flytte de studerendes indlæg fra deskription til refleksion:

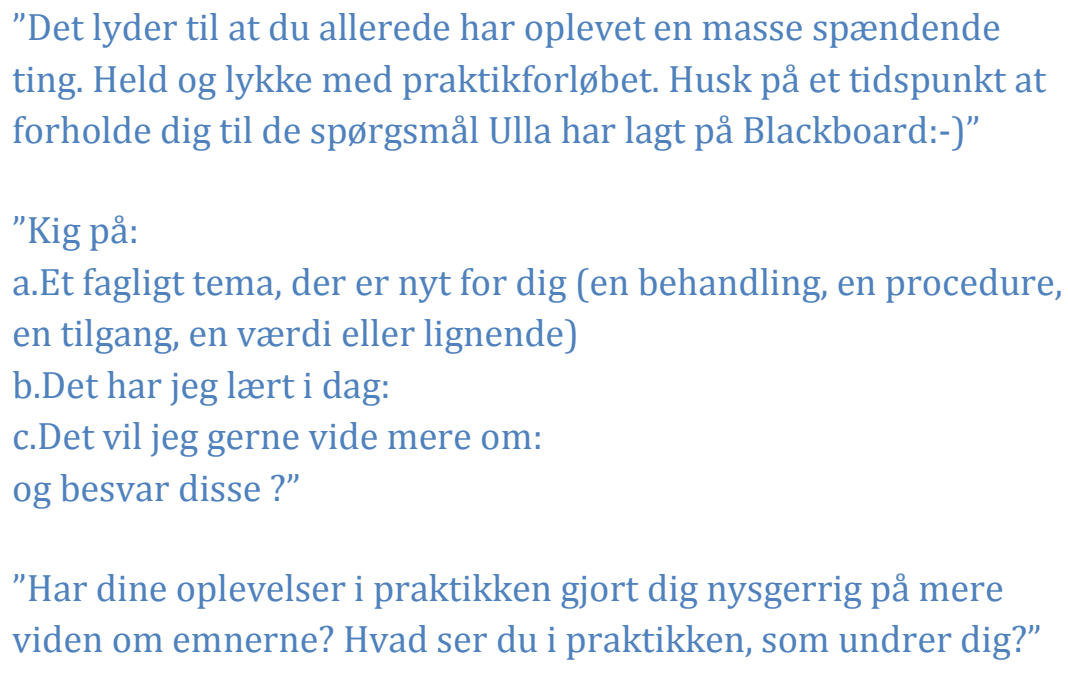

For at støtte refleksionen blev der i forbindelse med online dagbogen stillet en bunden opgave, hvor den studerende dagligt skulle besvare tre spørgsmål og til slut sammenfatte deres refleksioner. Da dagbogen læses løbende af en underviser, er det derfor muligt gennem kommentarerne at http://www.lom.dk 
hjælpe den studerende til at fokusere på refleksionen ved at henvise til den opgave, der er stillet. Denne metode bruges oftest, hvis den studerende primært er beskrivende i sine indlæg.

Hvis den studerende allerede reflekterer, men har behov for retning på refleksionen, eller hvis en dygtig studerende skal udfordres yderligere, kan underviseren stille specifikke refleksionsspørgsmål. Disse kan tage udgangspunkt i den studerendes oplevelser:

"Det lyder til at du klarer dig fint i praktikken, oplever meget og udvikler dig fagligt:-) Hvad tænker du om at TP på egen hånd foretog ex af to mælketænder (i forhold til lovgivning, etc)?"

"Du skriver at du "lærte i dag, hvordan man laver fissurforsegling på et rigtigt arbejdssted", prøv at uddyb hvad du mener med det??? Hvad tænker du om at tandplejeren pudser af med pudspasta inden fissurforsegling?"

"Jeg kunne godt tænke mig at du beskrev lidt mere om hvordan Ålborg Kommune sikrer kvaliteten i deres behandlinger. Både organisatorisk, afdeling /skole og for eget arbejde."

Men der kan også være tale om kommentarer, der tager udgangspunkt i de refleksioner, som den studerende allerede har gjort.

"God læsning. Mange refleksioner. Kan godt forstå du undrer dig over TP's ekstraktioner. Diskuterer I det?"

"Jeg er ikke forpligtiget til at kommenter på din dagbog men fandt det alligevel vigtigt at rose dig for din iagttagelse. Jeg vil gerne, om du vil uddybe det for mig når vi atter mødes på skolen. I hvilken sammenhæng var det at du så handlekompetence som vigtig viden? Og hvilken nytte kunne personalet have af at kende dette dannelsesperspektiv."

Fælles for disse kommentarer er, at underviseren bruger feed forward til at påvirke de videre refleksioner. Enten giver underviseren den studerende en fornemmelse af refleksion frem for deskription ved at eksemplificere, hvad der kan reflekteres over, eller også får den studerende redskaber til udvidelse af refleksionen. Alle steder besvares feed forward spørgsmålet: Where to next? 


\title{
Kommentarer der skal vise den studerende vej mod ny viden
}

En sidste type af kommentarer er de kommentarer, der med udgangspunkt i den studerendes interesser henviser til, hvor der kan findes ny viden om det pågældende interesseområde. Dette kan være kommentarer som:

\author{
"Underetninger kan man læse om på kommunes hjemmeside. Der \\ skal gerne være en fuldstændig retningslinje for hvordan man \\ gør. Man skal jo som fagperson, eller nabo kunne kende \\ proceduren, prøv at se der!" \\ "Hvis du vil læse mere om mineraliseringsforstyrrelse i \\ tandemaljen kan du Google: \\ Dorte Haubek, professor i Pædodonti på IO. Hun har for nylig \\ publiceret et skrift som hedder Molar Incisiv Hypomineralisation \\ (MIH). Det er et let læseligt skrift med mange gode billeder. \\ Skriftet er lavet i samarbejde med Zendium."
}

Igen er der tale om feed forward, der tager udgangspunkt i den enkelte studerende og peger frem imod kommende opgaver.

\section{Timing og kvalitet i kommentarerne}

Samlet kan man sige om kommentarerne, at de i modsætning til feed back på f.eks. en praktikrapport giver underviseren mulighed for at give den studerende feed back løbende i praktikforløbet og derved give feed back, der stadig kan nå at blive omsat til handlinger og refleksioner under selve forløbet. Den helt store kvalitet ved online kommentaren er derfor muligheden for at time kommentarerne og give rettidig feedback.

For at udnytte denne timing er det væsentligt at give feedback, der indeholder både feed back, feed forward og feed up. På tandplejeruddannelsen benyttes da også både feed back på, hvordan det går og feed forward, der giver de studerende retningslinjer for de næste skridt. Dette sker dog ikke struktureret, og man kunne overveje, om en egentlig feedbackstrategi vil være en fordel for at sikre, at feedbacken ikke kun er rettidig, men også til alle studerende indeholder både feed back, feed forward og feed up.

\section{Udbyttet af online dagbogen}

Tandplejeruddannelsen på Aarhus Universitet har haft stort udbytte af at benytte dagbogsrefleksioner i forbindelse med praktik, og dette gælder både for undervisere og studerende.

Først og fremmest har det været en fordel, at dagbogen er ført online i et værktøj, som decideret er beregnet til formålet. Underviserne har haft 
overblik over indlæggene og de kommentarer, der blev afgivet. Dette nævnes især som en modsætning til et mailsystem, hvor en underviser selv må skabe struktur ved hjælp af mapper. Dette prøvede en underviser med en enkelt studerende, der ikke havde adgang til læringsplatformen. Med dagbogsværktøjet er det muligt at sammenkæde de studerende med de enkelte indlæg og tilhørende kommentarer, samtidig med at indlæggene samles i en struktur i forhold til, hvornår de er skrevet.

For den studerende er der de samme muligheder for overblik over egne indlæg og kommentarer på disse. Det er desuden en fordel, at dagbogen findes sammen med øvrigt læringsmateriale og værktøjer på en læringsplatform, hvor den studerende i forvejen logger ind dagligt.

Undervisere og studerende har derfor både tekniske og administrative fordele ved at benytte dagbogen, men også på indholdssiden har der været et udbytte.

For underviserne har det været rigtig godt at kunne følge med i, hvad der sker ude i praktikken, og flere har oplevet, at de i forløbet begyndte at læse dagbøger skrevet af studerende, de ikke selv er kontaktlærer for.

Undervisere, der er fuldtidsansatte på universitetet, får derfor indsigt i en hverdag, de ikke længere selv er en del af, mens deltidsansatte undervisere får en anden vinkel på den del af deres dagligdag, som foregår i den offentlige eller private tandpleje.

For de studerende er der, som beskrevet ovenfor, i høj grad tale om et læringsmæssigt udbytte. Men desuden beskriver underviserne, hvordan fokus på refleksion omkring faglig praksis gennem hele uddannelsen skaber mere selvstændige tandplejere, der med kritisk blik kan og tør kommunikere fagligt.

Udbyttet for den studerende bliver derfor ikke blot en refleksion over egen praksis og de læringsmæssige fordele, som det medfører, men refleksionen bliver et redskab til gennem uddannelsen at skabe selvstændige tandplejere, der kan bruge refleksioner og værktøjer til refleksion i nye sammenhænge.

\section{Erfaringer med dagbogen}

I dette afsnit vil der blive samlet op på erfaringer med online dagbogen med det formål at kunne udnytte erfaringerne i praksis til selv at arbejde med dagbogen i praktik- eller klinikforløb. I opsamlingen vil både indgå erfaringerne fra tandplejeruddannelsen på Aarhus Universitet og fra School of Nursing, Southeastern Louisiana University (SLU), hvor dagbogen (The reflective journal) har været brugt som et værktøj til udvikling af refleksive praktikere. 
På School of Nursing, SLU har man defineret en række guidelines til brug for undervisere, der selv vil i gang med at benytte online dagbogen (Kessler \& Lund, 2004). Disse er:

- Refleksion, ikke deskription

- Proces, ikke produkt

- Kvalitet, ikke længde

- Sikkerhed, ikke sanktioner

\section{Refleksion, ikke deskription}

Med hensyn til punktet omkring refleksion, ikke deskription beskriver Kessler og Lund vigtigheden af at lære de studerende at skrive refleksivt, og de beskriver en metode, hvor de studerende både får et overblik over refleksiv læring og præsenteres for en guide med eksempler på dagbogsrefleksioner. Kessler og Lund peger ligeledes på, at det er vigtigt at hjælpe de studerende med at skelne imellem deres tanker i forbindelse med de hændelser, de beskriver (reflection-in-action) og deres efterfølgende tanker om hændelsen (reflection-on-action).

Netop opgaven med at hjælpe de studerende til refleksion frem for deskription er også central for underviserne på tandplejeruddannelsen. Først og fremmest har man her stillet en bunden opgave, hvor den studerende dagligt skal besvare spørgsmål, der lægger op til refleksion. Dette skal sikre, at de besvarelser, der kommer ind, ikke er en opremsning af den studerendes handlinger gennem dagen, men derimod den studerendes refleksioner over disse handlinger. Den studerende holdes desuden fast på spørgsmålene og udfordres yderligere gennem de kommentarer, som underviserne skriver til deres dagbogsindlæg. Dette gælder specielt for den kommentartyper, der tilskynder videre refleksion.

\section{Proces, ikke produkt}

Den næste guideline handler om at fokusere på processen frem for produktet, det vil sige, at den studerende i sine indlæg skal fokusere på årsagen til og konsekvenser af tanker, handlinger og følelser frem for det præcise indhold af disse. Den studerende bør altså udforske, hvad der kommer før, og hvad der sker efter en begivenhed frem for at lægge hele vægten på begivenheden selv.

\section{Kvalitet ikke længde}

Ifølge Kessler og Lund er det vigtigt, at den studerende ved, at der ikke er noget krav til længden på et dagbogsindlæg. Den studerende skal skrive hver dag, og underviseren skal læse ofte, derfor er det vigtigt at holde en længde, der gør, at dagbogen bliver en overkommelig opgave i en tid, hvor den studerende samtidig har travlt med at tilegne sig de praktiske 
erfaringer, der er rammen for dagbogen, f.eks. gennem praktik eller klinikophold.

Dette punkt bliver også overvejet på tandplejeruddannelsen, hvor dagbogsindlæg har meget svingende længde. Her beskriver underviserne, hvordan nogle indlæg fylder meget, mens andre næsten intet skriver i deres indlæg. Dette lægges der ikke vægt på i kommentarerne, hvor fokus er på, om de studerende får reflekteret i forhold til den stillede opgave.

\section{Sikkerhed, ikke sanktioner}

Det sidste punkt, som beskrives af Kessler og Lund, handler om at give de studerende tryghed i dagbogsskrivningen, da den refleksive dagbog er en personlig tekst, hvor den studerende udstiller egne følelser og holdninger. Dagbogen skal derfor give den studerende et frirum til de personlige refleksioner, uden at den studerende behøver at frygte for at blive personligt bedømt.

På tandplejeruddannelsen har man været opmærksomme på, at dagbogen i modsætning til bloggen er et personligt værktøj. De studerende kan ikke se hinandens indlæg, men underviserne har adgang til alle, hvilket blev meldt ud fra begyndelsen. Ligeledes har der været opmærksomhed omkring den frihed i udtrykket, som dagbogen lægger op til. Underviserne har ikke rettet hverken grammatik eller sprogbrug med mindre dette havde en faglig eller indholdsmæssig betydning. Eksempelvis blev der lagt vægt på, at det tandfaglige sprog var i orden.

\section{Tid til e-moderation}

E-moderatoren er den person, der medierer interaktion og samarbejde i online miljøer (Salmon, 2004). Selv om online dagbogen er personlig, er underviseres rolle dog stadig den samme som e-moderatorens, hvad angår at skabe tryghed i miljøet, og gennem kommentarerne at støtte og lede den studerende på rette vej.

Ovenstående afsnit beskriver guidelines med fokus på hjælp til de studerende i deres arbejde med refleksive dagbogsindlæg, men den største udfordring med dagbogen kan meget vel være at frigive tid nok for underviserne eller e-moderatorerne til at varetage den store opgave, det er at kommentere og give feedback. Da det er undervisernes kommentarer, der er online dagbogens største styrke, skal disse udfordringer diskuteres nærmere her.

På tandplejeruddannelsen har det først og fremmest været vigtigt at lade det være op til hver enkelt underviser, hvordan man vil tilrettelægge opgaven. Det har ikke været aftalt på forhånd, at kommentarmuligheden skulle bruges, eller at kommentarerne skulle have en bestemt længde eller en bestemt form, og de fleste kommentarer er derfor meget korte og 
centreret omkring kernebudskabet. Det har været vigtigt i disse første erfaringer med online dagbogen at sætte realistiske mål og forventningsafstemme målene med de studerende. Således har de studerende vidst, at deres dagbogsindlæg ville blive læst løbende, men også at de ikke nødvendigvis kunne forvente at få kommentarer. Alle studerende har dog fået kommentarer i perioden.

Ligeledes har man valgt kun at stille én opgave til de studerende. I et længere praktikforløb kunne man meget vel have valgt at skifte den bundne opgave ud undervejs, men for både undervisere og studerende sparer det tid kun at skulle fokusere på den samme opgave gennem hele forløbet.

Endelig har det været vigtigt at holde fokus på målet og på, hvad man ville opnå med dagbogen. Derved kan man sortere kommentarer fra, der omhandler alt andet. Da refleksionen er det essentielle, skal kommentarerne primært støtte op omkring de studerendes refleksion eller have andre væsentlige formål, som at styrke den studerendes tro på sig selv i praktikforløbet eller vise vej mod ny viden. Kommentarer der eksempelvis omhandler form og udtryk udelades.

Tiltagene, der har været gjort på tandplejeruddannelsen, har været effektive i opstartsfasen og for at få implementeret det nye værktøj i uddannelsen. På sigt bør det dog overvejes, hvordan man reelt får frigivet mere tid til feed back-arbejdet, således at der bliver ressourcer til uddybende og struktureret feed back og til at afgive feed back hyppigt og rettidigt.

Dette kan gøres via reel undervisningsomlægning og omstrukturering af undervisernes arbejde, hvilket vil være en understøttelse og anerkendelse af den læring, som foregår via online læringssystemer.

Et alternativ er at udnytte muligheden for at arbejde med online dagbogen $\mathrm{i}$ studiegrupper. Det er en væsentlig pointe hos Salmon, at e-moderatorens rolle kan uddelegeres, så rollen eksempelvis kan varetages af en studerende. På denne måde understøttes samspilsprocesserne mellem de studerende (Illeris, 2006), samtidig med at underviserressourcer minimeres.

Denne model kan lade sig gøre med dagbogsværktøjet, hvor grupper på forhånd kan defineres, således at indlæg og kommentarer forbliver private inden for gruppen. Herefter kan medlemmer af gruppen læse og kommentere hinandens dagbogsindlæg. Fokus bør da være på oplæring af de studerende, både for at bevare refleksive dagbogsindlæg af høj kvalitet og for at skabe et trygt dagbogsmiljø for den enkelte studerende. Til gengæld kan man understøtte målet om at skabe selvstændige studerende, der tør tage de faglige diskussioner. 


\section{Konklusion}

Refleksion er vigtig fordi refleksion styrker selvtilliden i forhold til det lærte og har indflydelse på, om den studerende kan bruge det, der er lært, i nye sammenhænge. I praktik og klinikophold, hvor den studerende ikke har kontakt med uddannelsesstedet, kan det være svært at understøtte den studerendes refleksioner over de praktiske handlinger. Her kan en online dagbog i den studerendes daglige learning management system være en hjælp, specielt hvis indlæg understøttes af kommentarer fra underviserne.

Når den studerende i praktikforløbet støder på udfordringer og standser op og overvejer, hvordan udfordringerne kan håndteres, reflekterer den studerende i handlingen (Refleksion-in-action). Når dagen er omme, og handlingerne igen gennemtænkes, er der derimod tale om reflection-onaction, en refleksion, der gennem online dagbogen gentages, således at den studerende i sammenligning med en praktikrapport går fra et refleksionsloop til en refleksionsspiral.

Online dagbogens helt store styrke er dog kommentarerne, der betyder, at underviseren har mulighed for at bryde ind undervejs i refleksionsspiralen og påvirke den studerendes videre refleksion og praktikforløb med feed back, der giver den studerende en tryg linje til uddannelsesstedet, tilskynder refleksion og viser vej mod ny viden.

Online dagbogen giver mulighed for at time feed back til den studerende, men det kan være vanskeligt for en underviser at få tid til hyppige og strukturerede kommentarer, der indeholder alle tre feed back-aspekter. Derfor kan det for at komme i gang være nyttigt at holde fokus på en fast defineret, afgrænset opgave og forventningsafstemme målet og opgaven med de studerende, både hvad angår de studerendes refleksioner og undervisernes kommentarer.

Med tiden bør man dog overveje at benytte metoder som omstrukturering af undervisningen eller gruppe-feed back for at frigive tid og sikre feed back-kvaliteten til alle studerende. 


\section{Referencer}

Fredens, K. (2012). Mennesket i hjernen: En grundbog i neuropædagogik. København: Hans Reitzels Forlag.

Hattie, J, \& Timperley, H. (2007). The power of feedback. Review of Educational Research March 2007, Vol. 77, No. 1, pp. 81-112 DOI: 10.3102/003465430298487

Retrieved from: http://rer.sagepub.com/content/77/1/81.long

Illeris, K. (2006). Læring. Frederiksberg: Roskilde Universitetsforlag

Kessler, P. D., \& Lund, C. H. (2004). Reflective journaling: Developing an online journal for distance education. Nurse Educator: January/February 2004 - Volume 29 - Issue 1 - pp 20-24 Retrieved from: http://journals.lww.com/nurseeducatoronline/Abstract/2004/01000/ Reflective_Journaling__Developing_an_Online.7.aspx

Salmon, G. (2004). E-moderating: The key to teaching and learning online. London: Taylor and Francis Books Ltd.

Schön, D. A. (1991). Educating the reflective practitioner: toward a new design for teaching and learning in the professions. San Francisco: Jossey-Bass.

Schön, D. A. (1995). The new scholarship requires a new epistemology. Change; Nov/Dec95, Vol 27 Issue 6, p26, 9p, 4c Retrieved from: http://bonnernetwork.pbworks.com/w/file/fetch/59896448/Schoen\% 20Scholarship\%20New\%20Epistemology.pdf

Aarhus Universitet. (2011). Politik for Educational IT. 